\title{
CHI3L1 Gene
}

National Cancer Institute

\section{Source}

National Cancer Institute. CHI3L1 Gene. NCI Thesaurus. Code C125183.

This gene plays a role in carbohydrate binding, inflammation and tissue remodeling. 